\title{
ALISE 2019: Exploring Learning in a Global Information Context
}

\author{
Xiaoai Ren \\ Valdosta State University, Valdosta, Georgia, USA
}

The Association for Library and Information Science Education (ALISE) commits to serve as the international leader in both education practice and research for established and emerging career opportunities in the information professions. Its 2019 annual conference was held in Knoxville, Tennessee from September 24-26 ${ }^{\text {th }}$. A total of 282 people, including 76 first time attendees, traveled from eight countries - USA, Canada, China, Germany, Jamaica, South Africa, United Arab Emirates, and the United Kingdom to participate.

This year's conference theme is Exploring Learning in a Global Information Context. It is to encourage engagement across the globe from LIS educators and scholars from a wide variety of relevant fields to share their vision for education, for teaching and learning, for pedagogy, and for research through an international lens. This year's keynote speaker is Dr. Jaya Raju. She is Associate Professor and Head of the Library and Information Studies Centre at the University of Cape Town, South Africa. Her talk is "Shaping LIS Education for Blended Professionals in a Pluralist Information Environment: Global Reflections." She emphasized the importance for LIS professionals to be equipped with both technology and pedagogical skills in a digitized information environment. Librarians now must blend traditional skills with hardware/software skills, and the educational designers' ability to apply technology appropriately to teaching and learning. She drew on findings from research on curriculum development directed at the hybrid LIS professional in a pluralist information environment which requires cross-disciplinary competencies spanning LIS, IT, Teaching and Learning, and other relevant areas.

There are eight sessions during the three-day conference. Each session includes five concurrent programs, juried panel, juried paper and lasts 1.5 hours. The topics covered during these sessions include but are not limited to: innovative teaching methods \& strategies, diversity, accessibility, information ethics, information policies and many more.

Doctoral Student Research Poster Competition is always one of the highlights of the conference. This year, 19 doctoral students entered the ALISE/Jean Tague-Sutcliffe Doctoral Student Research Poster Competition. The first place winner is Megan Threats from the University of North Carolina - Chapel Hill. Her poster presentation was titled "The Influence of SocioTechnical Environments on the Information Behaviors and HIV Risk Reduction Behaviors of Black Gay Men.” Her study investigates how and where young black men who have sex with men (YBMSM) access and interact with HIV/STI-related information. She used online survey and semi-structured, in-depth interviews to explore and explain the associations between information behavior, technology usage, and HIV risk reduction behaviors among YBMSM.

In 2019 ALISE annual conference, ALISE also organized its business meetings, committee meetings, and planning meetings. The winners of ALISE 2019 awards were announced during the 
2019 awards luncheon. There are six ALISE awards, three Annual Conference Awards and Grants, and four ALISE Research Awards and Grants. Seventeen individuals were recognized at this event.

As a vital resource in connecting schools and potential faculty members, ALISE also provide placement services. Key components of Placement Services include job postings, access to student resumes, and accommodations to conduct interviews onsite at the conference. This year, nine member schools participated in the placement services at the conference.

The 2019 ALISE annual conference also announced the theme of the 2020 ALISE annual conference: Transforming LIS Education in an Interconnected World. It will be held in Pittsburgh, Pennsylvania in October 2020.

Please refer to ALISE2019 website (https://www.alise.org/alise-2019-conference) for further information. 